\title{
Kyoto for commuters
}

\section{Offset schemes are a small but potentially useful addition to the carbon balance sheet.}

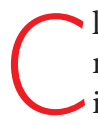
limate change, as we are now experiencing it, is predominantly the result of the lifestyles to which people living in the industrialized world have grown accustomed. One increasingly popular response to it is carbon offsetting, a practice that allows people to compensate for the impact of their activities by supporting climate-friendly projects in distant corners of the world. It is a promising approach - even if some of its early manifestations are being dangerously oversold (see page 976).

Some of the more popular carbon offsetting schemes allow consumers to buy credits on an emerging, but unregulated, voluntary emissions market, to compensate for carbon-emitting behaviour such as air travel, commuting or home heating. Outfits such as the CarbonNeutral Company in London or Atmosfair in Bonn will sell such credits for a few euros, or tens of euros. The money will ultimately be used, they say, to reduce carbon emissions in regions of the world where it is inexpensive to do so: for example, households in India or Peru might switch to using their own locally produced biofuels for cooking.

Industrial companies and organizers of large events, such as the 2006 World Cup, are also able to buy credits for larger-scale energy projects to offset their emissions in the same way.

The principle of carbon offsetting makes sense because it makes no difference to the atmosphere where carbon emissions are reduced, as long as they happen. It has rapidly become quite fashionable in some countries, notably Britain and Germany, where an improbable alliance of green groups, travel agencies and corporations have rallied behind it. Global concern about climate change, it would appear, is creating a new breed of responsible consumer, whose participation may serve to reduce global pollution and poverty.

So much goodwill at once is arousing some suspicion. But the idea should not be dismissed out of hand. At its best, voluntary carbon offsetting is an elegant way of mixing capitalism and sentiment in the fight against global warming.

The voluntary market has many problems, however, and not every offset project will deliver the emissions cuts promised. More transparency and better regulation would make offsetting schemes more attractive to those who remain sceptical of their value. The United
Nations Climate Secretariat, which oversees mandatory emissions trading under the Kyoto Protocol, and national bodies such as the UK Financial Services Authority, need to work together on the accreditation of schemes that participate in the emerging, voluntary market, and the regulation of the way they are sold to consumers. Yet it is important that the accreditation is not so heavy-handed that it kills off the small, inexpensive projects that need to materialize if carbon offsetting is to work.

Until such accreditation is in place, the idea should not be oversold. The cuts that can be achieved in this way in poor nations are somewhat limited in scope, and encouraging them should not be seen as a substitute for the political action needed to reduce emissions in industrialized countries. Consumption, mobility, global tourism and many other aspects of modern life are going to have to change if global warming is to be confronted effectively.

Unwillingness to acknowledge that existing lifestyle choices may be incompatible with the need to confront the problem is a theme that comes up repeatedly in climate debates. After all, it is not just George W. Bush, Tony Blair and Angela Merkel who are failing to adequately address the issue. Consumers of goods and services that depend on the burning of fossil fuels also have a role to play.

There is obviously a danger that the procurement of credits on such a scheme may induce self-satisfaction, complacency and perhaps even extravagance on the part of a few individuals.
"At its best, voluntary carbon offsetting is an elegant way of mixing capitalism and sentiment in the fight against global warming."
However, this effect is small compared with the general raising of public consciousness on the issue of global warming that is encouraged by the high profile of the offsetting plans.

Carbon offsetting is becoming popular as individuals and businesses begin to recognize this. Whether they are acting for ethical reasons, or simply in response to the preferences of investors, customers and employees, the final effect remains beneficial — provided that the low-carbon projects that get a boost as a result are properly devised, implemented and monitored.

\section{Peer review and fraud}

\section{Two assessments of the refereeing process highlight challenges for journals.}

t would be misguided indeed for Nature to have any competitor's sense of Schadenfreude over Science's experiences with two papers on human embryonic stem cells by Woo Suk Hwang and his colleagues. It is possible that we at Nature would have published the papers had they been submitted to us instead.

The external review committee, which included Nature's US executive editor Linda Miller, earlier this month endorsed the general level of care exercised by Science. It also stated that, cumulatively, concerns raised during the refereeing processes should have been pursued more sceptically. Hindsight is always 20/20, however, and it is not at all clear that the questions were sufficiently pressing that any journal would have pursued them, given the degree of trust that is required between authors and editors.

It is precisely this degree of trust that the review panel goes on to 